\title{
Within water-body management: a needed but neglected complement to watershed management
}

\author{
H. Kenneth Hudnell
}

Received: 13 April 2010/Accepted: 18 May 2010/Published online: 5 June 2010

(C) Springer-Verlag 2010

Recent assessments by the U. S. Environmental Protection Agency indicate that $44 \%$ of river and stream miles and $64 \%$ of lake and reservoir acres are impaired pursuant to section 305(b) of the U.S. Clean Water Act (E.P.A. 2009a). The impairments are caused by the transfer of nutrients, toxic substances and pathogens from watersheds, and to a lesser extent airsheds, to receiving waters. Eutrophication, the processes through which the flux of growth-limiting nutrients from watersheds to receiving waters stimulates excessive plant growth such as freshwater harmful algal blooms (FHABs), continues to increase (Hudnell 2008). Analyses of data from EPA's first eutrophication survey conducted in 1972 indicated that 10-20\% of all U.S. lakes and reservoirs were eutrophic (Gakstatter and Maloney 1975). The Agency recently reported that over $50 \%$ of all U.S. lakes and reservoirs are eutrophic or hypereutrophic (E.P.A. 2009b). This alarming rate of increase signals the need for an evaluation of surface-water management and restoration policy, and identification of methods for reversing this trend, if we are to have a sustainable supply of usable freshwater.

U.S. policy has long focused on limiting the transfer of pollutants into receiving waters. Wastewater utilities and other point sources have been regulated through National Pollution Discharge Elimination System (NPDES) standards since 1972. NPDES limits on pollutant discharge levels greatly reduced point source discharges, although

H. K. Hudnell ( $\square)$

Science office, SolarBee Inc., Dickinson, ND 58601, USA

e-mail: kenhud@SolarBee.com

H. K. Hudnell

Institute for the Environment, University of North Carolina, Chapel Hill, NC 27517, USA additional reductions of pollutant discharges in municipal storm water are needed. Nonpoint source pollutant discharges are estimated to be about 20 times those of point sources (Gianessi and Peskin 1984). Local jurisdictions are required to develop lists of impaired water bodies, prioritize those water bodies based on the ecosystem services they provide such as drinking source waters, fisheries and recreation, and calculate Total Maximum Daily Loads (TMDLs) that will enable the water bodies to meet water quality standards. However, the development of TMDLs has been slow, and achievement of those reduced input levels even slower.

Nonpoint source pollutant control primarily relies on best management practices for soil conservation and watershed management to achieve TMDL levels. Yet more than seven decades of soil conservation policy and almost four decades of watershed management policy, each with current Federal expenditures of $>\$ 5$ billion annually and even larger expenditures by local jurisdictions, failed to reverse the trend of increasing eutrophication (Hansen and Ribaudo 2008; E.P.A. 2009c). That failure can be attributed in part to the disparate array of U.S. legislation, water policies, and management programs. An integrated National water policy is needed to reverse the trend of water quality degradation while balancing the Nation's social, environmental, and economic needs (Clean Water America Alliance 2009). The combination of improved legislation, policy, and management methods is essential for achieving near-term reductions of the risks posed by water-body impairment to human and animal health, aquatic-ecosystem sustainability, and economies (Hudnell 2010).

Key to developing an integrated National water policy is acknowledgment that soil conservation and watershed management practices are very long-term approaches to 
water quality improvement. This acknowledgment coupled with the alarming rate of water quality degradation is a clear indication of the need for near-term solutions to water quality problems. Water quality can be improved in the near term only through within water-body treatment. Within water-body management is the natural complement to soil conservation and watershed management policies. A policy of within water-body management acknowledges that impaired water bodies are akin to ill human bodies; that supportive, anti-pollutant therapies are required to maintain and improve the function of stressed aquatic ecological processes in the near term. Just as a holistic approach to human health encompasses sound lifestyle, environmental and medical practices, a holistic approach to water quality requires both watershed and within waterbody management practices.

Innovative and coordinated approaches to within waterbody management can be developed and implemented to improve surface-water quality in the near term as we continue the long-term effort to limit the flux of pollutants from watersheds to water bodies. Within water-body management methods based on ecological principals (Hudnell 2010) can support the function of the stressed ecological processes that historically maintained healthy aquatic ecosystems (Karr and Dudley 1981). For example, hypolimnetic anoxia can be eliminated through artificial circulation. Hypolimnetic anoxia commonly occurs in eutrophic water bodies when aerobic bacteria deplete dissolved oxygen while decomposing organic material, presenting risks for ecological processes and human health. Oxygen depletion not only causes fish kills, but also promotes the methylation of mercury and the release of pollutants such as manganese and phosphorus from sediment to the water column (Borch et al. 2010). Depositions from atmospheric emissions are the primary source of inorganic mercury in water (Rudd 1995). Anaerobic bacteria at the sediment-water interface and in the water column attach a methyl group to mercury under anoxic conditions (Xun et al. 1987). The highly potent developmental neurotoxin, methylmercury (Trasande et al. 2005), bioaccumulates and biomagnifies as it ascends through trophic levels of the food web (Watras et al. 1998). The U.S. Food and Drug Administration set a maximum permissible level of $1 \mathrm{ppm}$ methylmercury in commercial seafood (F.D.A. 1994). Advisories in many areas warn that pregnant women and children should avoid or severely limit their consumption of fish from local water bodies due to methylmercury contamination.

Manganese, another neurotoxic substance (Hudnell 1999), dissolves from sediment to the water column during anoxic events (Borch et al. 2010). Manganese levels above $0.05 \mathrm{mg} / \mathrm{l}$, the EPA secondary maximum contaminant level, cause aesthetic and operational problems in water utilities (E.P.A. 2004). Long-term consumption of water containing manganese at concentrations above $0.4 \mathrm{mg} / \mathrm{l}$ is associated with adverse human-health effects (W.H.O. 2004).

The release of dissolved phosphorus from sediment to the water column stimulates FHABs (Hudnell 2008). FHABs are primarily caused by cyanobacteria (blue-green algae), many of which produce cyanotoxins, among the most potent toxins known (Hudnell 2010). The demise of blooms is frequently accompanied by anoxic events during FHAB cell decomposition, completing a cycle of anoxia, phosphorus release, FHAB, FHAB die off, and anoxia (Hudnell 2008; Lopez et al. 2008). Within water-body management has the potential to eliminate anoxia, and the associated ecological and health risks, through oxygenation of the hypolimnion. The advent of artificial-circulation technologies powered by solar panels and batteries reduced the cost of aeration by eliminated the need for electricalgrid power and air condensers (Hudnell et al. 2010). Anoxia can be eliminated by continuously circulating water between the hypolimnion and surface where oxygen diffuses from air to water. Solar-powered circulation eliminates anoxia and the associated ecological and human-health risks without greenhouse gas emissions.

Quiescent or stagnant water is another stimulatory factor for FHABs (Hudnell 2008). Freshwater flow rates are decreasing as drought frequency and duration increase due to global climate change, and withdrawals increase due to rising usage demand (Hudnell 2008). The combination of nutrient enrichment and decreased flow rates is the primary cause of increasing FHAB incidence in freshwater bodies (Hudnell 2008). Recent evidence indicates that artificial circulation through solar-powered circulation suppresses FHABs even in nutrient-enriched water bodies (Hudnell et al. 2010). Unlike oxygenation of the hypolimnion, FHAB suppression is achieved by circulating only the epilimnion or photic zone in which FHABs occur. The circulation units are spaced at an average density of one unit $/ 0.15 \mathrm{~km}^{2}$ (35 ac). Solar-powered circulation suppresses FHABs while promoting beneficial algae and eliminating the need for chemical algaecide treatments that also adversely impact aquatic biota (Hudnell et al. 2010). The suppression of FHABs without algaecides creates robust fisheries by enabling nutrients to move up the food web from edible, chlorophyta (green algae) to zooplankton to filter feeding and carnivorous fish that can be harvested. Nutrients do not degrade water quality when channeled to the highest trophic levels; they become valuable resources for human consumption and commercial applications.

Artificial circulation and additional within water-body management technologies could target the removal, deactivation, and/or sequestration of the pollutants already present in impaired water bodies. Can pathogens in the 
water column due to surface runoff be deactivated by ultraviolet light when repeatedly exposed at the surface through circulation (Chang et al. 1985)? Can phosphorus be recaptured in surface waters for reuse to counter depletion of all the world's land-based reserves within 50-70 years (Déry and Anderson 2007)? Can hydrogen sulfide and other toxic and malodorous sulfur compounds be oxidized to odorless and less toxic sulfate? Can arsenic be coagulated and captured or precipitated to sediment in source waters? Can water utility infrastructure and operational costs be stabilized or reduced by improving source water quality through reductions in total suspended solids and biochemical oxygen demand? Can freshwater ecosystem services be restored and protected using the same technologies? Answers to these and similar questions require systematic research. Yet it is clear that soil conservation and watershed management policies alone are insufficient for improving freshwater quality in the near term or ensuring a sustainable supply of usable water in the long term. Increasing freshwater impairment and eutrophication imperil human and animal health, freshwater ecosystems and our economy. The time has come to further develop and assess the potential of environmentally sustainable, within water-body management technologies as complements to watershed management practices. This combination of approaches to surface-water management could be a significant step toward developing an improved and integrated National water policy.

Conflict of interest statement The author resigned from the US Environmental Protection Agency after serving as a neurotoxicologist for 23 years. He then joined SolarBee, Inc., a company that develops and manufactures solar-powered, long-distance circulation technology.

\section{References}

Borch T, Kretzschmar R, Kappler A, Cappellen PV, Ginder-Vogel M, Voegelin A, Campbell K (2010) Biogeochemical redox precesses and their impact on contaminant dynamics. Environ Sci Technol 44:15-23

Chang JC, Ossoff SF, Lobe DC, Dorfman MH, Dumais CM, Qualls RG, Johnson JD (1985) UV inactivation of pathogenic and indicator microorganisms. Appl Environ Microbiol 49:13611365

Clean Water America Alliance (2009) A call to action: the need for an integrated national water policy-The Clean Water America Alliance's National dialogue report. Washington, DC, $15 \mathrm{p}$. http://www.CleanWaterAmericaAlliance.org. Accessed 17 Feb 2010

Déry P, Anderson B (2007) Peak phosphorus. Drumbeat. http://www.theoildrum.com/node/2882. Accessed 17 Feb 2010

E.P.A. (2004) Drinking water health advisory for manganese. U.S. Environmental Protection Agency, EPA-822-R-04-003, Washington, DC, $55 \mathrm{pp}$. http://www.epa.gov/safewater/ccl/pdfs/reg determine1/support_cc1_magnese_dwreport.pdf. Accessed 17 Feb 2010
E.P.A. (2009a) National water quality inventory: report to Congress, 2004 reporting cycle. U.S. Environmental Protection Agency, EPA 841-R-08-001, Washington, DC, 43 pp. http://www.epa.gov/305b/ 2004report/2004_305Breport.pdf. Accessed 17 Feb 2010

E.P.A. (2009b) National lakes assessment: a collaborative survey of the nation's lakes. U.S. Environmental Protection Agency, EPA 841-R-09-001, Washington, DC, 118 pp. http://www.epa.gov/ lakessurvey/pdf/nla_report_low_res.pdf. Accessed 17 Feb 2010

E.P.A. (2009c) Clean water state revolving fund programs: 2008 annual report. U.S. Environmental Protection Agency, EPA 841R-07-001, Washington, DC, 28 pp. http://www.epa.gov/owm/ cwfinance/cwsrf/cwsrf_ar2008_final.pdf. Accessed 17 Feb 2010

F.D.A. (1994) Mercury in fish: cause for concern? 7 pp. http:// www.enotalone.com/article/8224.html. Accessed 17 Feb 2010

Gakstatter JH, Maloney TE (1975) Potential impact of a detergent phosphorus ban on eutrophication in selected American lakes and streams. U.S. Environmental Protection Agency, Corvallis, OR, $15 \mathrm{pp}$

Gianessi LP, Peskin HM (1984) An overview of the RFF environmental data inventory-methods and preliminary results. Resources for the future, Washington, DC, $111 \mathrm{pp}$

Hansen L, Ribaudo M (2008) Economic measures of soil conservation benefits: regional values for policy assessment, TB-1922. U.S. Department of Agriculture, Economic Research Service, Washington, DC, $31 \mathrm{pp}$. http://www.ers.usda.gov/publications/ tb1922/. Accessed 17 Feb 2010

Hudnell HK (1999) Effects from environmental manganese exposures: a review of the evidence from non-occupational exposure studies. Neurotoxicology 20:379-398

Hudnell HK (ed) (2008) Cyanobacterial harmful algal blooms: state of the science and research needs. Adv Exp Med Assoc 619: 1-949. http://www.epa.gov/cyano_habs_symposium/. Accessed 17 Feb 2010

Hudnell HK (2010) The state of U.S. freshwater harmful algal blooms assessments, policy and legislation. Toxicon 55:1024-1034

Hudnell HK, Jones C, Labisi B, Lucero V, Hill DR, Eilers J (2010) Freshwater harmful algal bloom (FHAB) suppression with solar powered circulation (SPC). Harmful Algae 9:208-217

Karr JR, Dudley DR (1981) Ecological perspectives on water quality goals. Environ Manag 5:55-68

Lopez CB, Jewett EB, Dortch Q, Walton BT, Hudnell HK (2008) Scientific assessment of freshwater harmful algal blooms. Interagency working group on harmful algal blooms, hypoxia, and human health of the joint subcommittee on ocean science and technology, Washington, DC. http://www.cop.noaa.gov/stres sors/extremeevents/hab/habhrca/Reports_2004_08.html. Accessed 17 Feb 2010

Rudd JWM (1995) Sources of methyl mercury to freshwater ecosystems: a review. J Water Air Soil Pollut 80:697-713

Trasande L, Landrigan PJ, Schechter C (2005) Public health and economic consequences of methyl mercury toxicity to the developing brain. Environ Health Perspect 113:590-596

Watras CJ, Back RC, Halvorsen S, Hudson RJM, Morrison KA, Wente SP (1998) Bioaccumulation of mercury in pelagic freshwater food webs. Sci Total Environ 219:183-208

W.H.O. (2004) Manganese in drinking water-background document for development of WHO guidelines for drinking-water quality. WHO/SDE/WSH/03.04/104. World Health Organization, Geneva, $21 \mathrm{pp}$

Xun L, Campbell NER, Rudd JWM (1987) Measurements of specific rates of net methyl mercury production in the water column and surface sediments of acidified and circumneutral lakes. Can J Fish Aquat Sci 44:750-757 